\title{
Geospatial and visual modeling for exploring sediment source areas across the Sele river landscape, Italy
}

\author{
Nazzareno Diodato, ${ }^{1}$ Massimo Fagnano, ${ }^{2}$ Ines Alberico ${ }^{3}$ \\ 1 Met European Research Observatory, GEWEX \CEOP Network - World Climate Research \\ Programme, Benevento; ${ }^{2}$ DIAAT - Dipartimento Ingegneria Agraria e Agronomia del Territorio, \\ Università di Napoli Federico II; ${ }^{3}$ CIRAM - Centro Interdipartimentale di Ricerca Ambiente, \\ Università di Napoli Federico II, Italy
}

\begin{abstract}
This study uses the revised universal soil loss equation (RUSLE) and Geographic Information System technology to map erosion-prone areas in the Sele basin (Campania-Basilicata regions, southern Italy). Current land use/cover, soil erodibility and climate factors were evaluated to determine their effects on average annual soil loss. Geospatial technologies were applied to generate RUSLE factors and erosion map. Long-term soil losses were $53 \mathrm{Mg} \mathrm{ha}^{-1}$ per year averaged over an area of $2500 \mathrm{~km}^{2}$ and more than $30 \%$ of the Sele basin was subjected to soil losses higher than $20 \mathrm{Mg} \mathrm{ha}^{-1}$ per year. Data available in the study area allowed to estimate soil losses, but the absence of direct sediment measurements prevents an accurate evaluation of the model performance. Nevertheless, the results are similar to the ones from other studies, and provide useful preliminary information for landscape management and restoration.
\end{abstract}

\section{Introduction}

Hydrological modelling is described as the art to reconstruct the architecture of a largely unknown system, where the complex interaction between water and soil and the exchange of mass and energy between the functional components of a basin are not observable

Correspondence: Dr. Ines Alberico, CIRAM, Centro Interdipartimentale di Ricerca Ambiente, Università di Napoli Federico I, via Mezzocannone 16, Napoli, Italy. Tel. +39.081.2531111 - Fax: +39.081.25634645.

E-mail: ialberic@unina.it

Key words: RUSLE, GIS, geospatial techniques, soil erosion, southern Italy.

Acknowledgements: this study was financially supported by VECTOR Project (line 2- VULCOST, leaded by B. D’Argenio).

Received for publication: 14 February 2011

Accepted for publication: 8 March 2011.

(C) Copyright N. Diodato et al., 2011

Licensee PAGEPress, Italy

Italian Journal of Agronomy 2011; 6:e14

doi:10.4081/ija.2011.e14

This work is licensed under a Creative Commons Attribution NonCommercial 3.0 License (CC BY-NC 3.0).
(Savenije, 2009). In this context, evaluation of hydrologically damaged land can be conceived as an interdisciplinary research, where geospatial techniques can transfer theoretical knowledge in physics and mathematics toward applied disciplines such as bioclimatology, hydrogeomorphology and agriculture (Diodato and Ceccarelli, 2004).

Among the hydrological damaging events, water erosion is one of the most pervasive, but often the less visible form of land degradation. Its increase was related to prosperity decline in the Mediterranean Europe of the past (Bintliff, 2002). The impacts of erosion on soil productivity are particularly significant because soil losses are generally cumulative and, on a human timescale, permanent (Blaschke et al., 2000). Particularly at watershed scale, soil water erosion generates important environmental and socio-economic consequences such as: decrease in soil fertility and productivity, transformation of land into fallow land not suitable for reforestation, irreversible reduction in arable soil, increase in flooding events or diffuse pollution of river networks (Vezina et al., 2006).

Responding to the soil erosion hazards of the modern era, interest groups and policy-driving organizations worldwide fostered the development and use of techniques for landscape restoration. For instance, the European Commission adopted a communication on soil protection, endorsed by the Council of Ministers in June 2002 (Gobin et al., 2003). Erosion data collected in Southern Europe show that the amount of rainfall has a crucial effect on soil erosion. Generally, in hilly Mediterranean shrublands, increasing runoff and sediment loss were observed as rainfall decreased especially in regions with rainfall higher than 300-500 mm year-1 (Kosmas et al., 1997; Zuazo and Pleguezuelo, 2008). Consequently, rainfall aggressiveness - estimated by the erosivity index - has been often used to assess the soil erosion risk (Renschler et al., 1999; Le Bissonnais et al., 2002). In long-term soil loss evaluation, the universal soil loss equation (USLE; Wischmeier and Smith, 1978) is used. However, in USLE, as well as in its revised version RUSLE (Renard et al., 1997), the spatial variability of rainfall erosivity and soil erodibility are the major sources of uncertainty (Boardman, 1993; Wang et al., 2002).

In this paper, a geosaptial modeling of soils at basin scale is proposed to improve the evaluation of some RUSLE factors. This model was based on the potentiality of spatial analysis of geographic information system (GIS) framework and on geostatistical analysis. Many papers published in the last decade prove that GIS softwares are useful to assess soil erosion (Panagopoulos and Antunes, 2008; Terranova et al., 2009) even if its prediction remains difficult because of the different spatial scales characterizing the RUSLE factors and the date availability. Despite these difficulties, it remains necessary to define soil erosion and to map the erosional classes. This is the aim of the present work, for the Sele River basin (Campania, southern Italy) since this area is subjected to stormwater, especially in the agricultural and river-torrential areas (Camarasa Belmonte and Segura Beltrán, 2001; Diodato, 2005a), where it leads to erosional soil degradation 
processes, landslide and flash-flood events (Thornes and AlcantáraAyala, 1998; Ramos and Mulligan, 2003).

\section{Study area}

The Sele River basin $\left(3236 \mathrm{~km}^{2}\right)$ is located in the western (i.e. Tyrrhenian) side of southern Italy (Figure 1) and includes a large alluvial plain, that derives from the Pliocene to Quaternary aggradation of a structural depression located along the western margin of the southern Apennines, known as Salerno Gulf-Sele Plain graben (Ippolito et al., 1973; Bartole et al., 1984; Barra et al, 1999). The plain is about 400 $\mathrm{km}^{2}$ wide and shows a triangular shape delimited seaward by a straight sandy coast, stretching between the towns of Salerno and Agropoli, encircled landwards by a range of calcareous mountains (Lattari, Picentini, Alburni, and Soprano-Sottano mounts) as well as by the siliciclastic Cilento hills with a mean elevation of about 1000 and $400 \mathrm{~m}$ a.s.l., respectively.

The eastern most portion of this structural embayment is characterized by hills formed by very thick clastic wedge, known as Eboli Conglomerate lower-middle Pleistocene in age (Cinque et al., 1988). The southernmost portion of the plain is characterized by the presence of thick successions of travertine deposits known as Travertini di Paestum (Violante and D'Argenio, 2000; Amato et al., 2009). Seawards and laterally to the travertines, there is a narrow coastal plain characterized by Tyrrhenian beach-dune ridges interfingered with lagoonal and fluvio-palustrine deposits (Brancaccio et al., 1986, 1988; Barra et al., 1998). A younger coastal sector, including a dunal sandy system elevated 1 to $5 \mathrm{~m}$ a.s.l., is interposed between the Tyrrhenian sandy-coastal ridge and the present shoreline.

The soil thickness in mountains and hill areas ranges from 50 to 150 $\mathrm{cm}$; andosols, luvisols cambisols and calcisols are the prevailing soils types. The andosols are developed on pyroclastic fall deposits and reached this area from the neapolitan volcanoes. The luvisols are developed on alluvial fan deposits and the cambisols- calcisols on calcareous-marly or clayey deposits. The highest thickness $(50$ to $>150 \mathrm{~cm}$ ) characterizes the alluvial and coastal plains, where cambisols, luvisols and arenosols are prevailing.

The climate in Sele basin is of Mediterranean type, with important spatial variation of both erosive rainfall and temperature, according to the elevation and the distance from the coast (Diodato and Fagnano, 2010). The mean annual precipitation, measured at 62 raingauges distributed across the entire catchment, ranges from 700 to $2000 \mathrm{~mm}$, with average $1180 \mathrm{~mm}$ and standard deviation $367 \mathrm{~mm}$.

The $52 \%$ of the area is covered by natural vegetation, mainly represented by decidous trees (36\%) and natural grasslands (9\%). The agricultural areas (45\%) are mainly represented by non irrigated arable crops (19\%), mixed cropping systems (12\%) and olive groves (7\%). The urbanized areas cover only $2 \%$ of the total Sele River basin (SRB) area.

\section{Methods and spatial modeling}

The average annual soil loss ( $\mathrm{E}$ in $\mathrm{Mg} \mathrm{ha}^{-1}$ ) due to water eosion per unit area and per year (30-years mean upon 1957-1996 period) is estimated by RUSLE (Renard et al., 1997):

$\mathrm{E}=\mathrm{R} \times \mathrm{K} \times \mathrm{LS}_{2 \mathrm{D}} \times \mathrm{C} \times \mathrm{P}$

where

$\mathrm{R}$ is the rainfall-runoff erosivity factor [ $\left.\mathrm{MJ} \mathrm{mm}(\mathrm{ha} \mathrm{h})^{-1}\right]$;

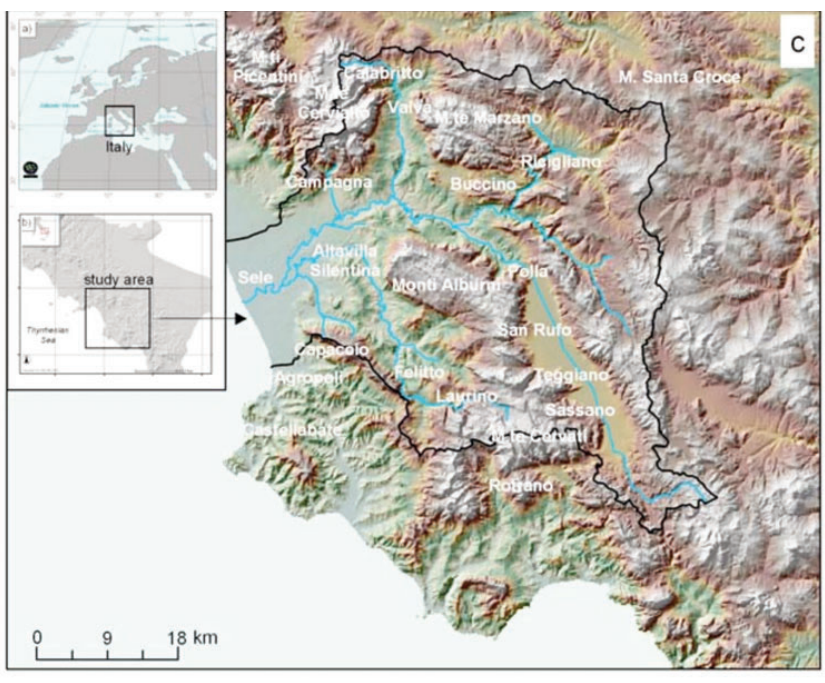

Figure 1. a) Geographical setting; b) peninsular Southern Italy; c) morphology of the Sele River Basin.

$\mathrm{K}$ is the soil erodibility factor [ $\mathrm{Mg}$ ha $\mathrm{h}$ (ha $\left.\mathrm{MJ} \mathrm{mm})^{-1}\right]$;

$\mathrm{LS} 2_{\mathrm{D}}$ is the two dimensional topographic factor, with $\mathrm{L}=$ length and $\mathrm{S}$ the slope steepness;

$\mathrm{C}$ is the cover and management factor;

$\mathrm{P}$ is the conservation support-practices factor.

The LS, $\mathrm{C}$, and $\mathrm{P}$ values are dimensionless. The accurate modelling of RUSLE factors is the crucial condition to obtain reliable results (Renschler and Harbor, 2002), especially in basins with low-resolution data (Diodato, 2005b) and scarce pedological samplings. The potentiality of spatial analysis, available in GIS environment, was used to define the $\mathrm{C}$ and LS factors as grid data, while climate (R) and soil factors (K) have been spatialized by using the kriging interpolaztion method (Burrough, 2001). Kriging provide statistically unbiased estimates of spatialized values starting from a set of sample points. The basic idea of kriging is to estimate the unknown attribute value at the unsampled location $\mathrm{s}_{0}$ as a wighted average of the neighboring observations $\left(\mathrm{s}_{\mathrm{i}}\right)$ :

$\mathrm{Z}\left(\mathrm{s}_{0}\right)=\lambda \mathrm{z}\left(\mathrm{s}_{\mathrm{i}}\right)$

where

$\mathrm{z}$ is a vector of the observed data (erosivity and erodibility) selected in the neighborhood location;

$\lambda$ is weight vector associated with the distance between $s_{0}$ and $s_{i}$; $\mathrm{Z}$ is the value at $\left(\mathrm{s}_{0}\right)$ prediction location (Johnston et al., 2001).

By multipliying the grids of all RUSLE factors, the soil erosion map of Sele Basin was drawn.

\section{Rainfall erosivity}

The available time series of meteorological variables don't record sub-hourly rainfall, limiting the application of USLERUSLE to obtain erosivity values. Diodato (2004), predicted annual erosivity from rainfall data of Southern Italy:

$R=12.142(0.000 \operatorname{Pr} \mathrm{d} \mathrm{h})^{0.6446}$

with $\mathrm{r}^{2}=0.867$ significant at $\mathrm{P}=0.01$, and where

$R$ is average annual rainfall erosivity;

Pr is the average annual rainfall ( $\mathrm{mm}$ );

$d$ is the annual mean max daily rainfall (mm); 
$h$ is the annual one hour max rainfall (mm).

\section{Soil erodibility}

Soil texture and organic matter data of soil samples were used to estimate soil erodibility (K) by using the equation from Torri $e t$ al. (1997):

$K=0.0293\left(0.65-D g+0.24 D g^{2}\right) e^{\left\{-0.021 \frac{O M}{C}-0.00037\left(\frac{O M}{C}\right)^{2}-4.02 C+1.72 c^{2}\right\}}(4)$

where

$K$ is the RUSLE erodibility factor $\left(\mathrm{Mg} \mathrm{h} \mathrm{MJ}^{-1} \mathrm{~mm}^{-1}\right)$ of the sampled locations;

$C$ is the \% of total clay;

$O M$ is the \% of organic matter;

$D g$ is a grain size parameter calculated by the equation of Shirazi $e t a l$. (1988):

$D_{\varepsilon}=\sum f_{i} \log _{10}\left(\sqrt{d_{i} d_{i-1}}\right)$

where

$f_{i}$ is the fraction of particles in the range of diameters $d_{i}$ and $d_{i-1}(\mathrm{~mm})$. For each particle size class (clay, silt, sand), $d_{i}$ is the max diameter (mm), $d_{i-1}$ is the min diameter and $f_{i}$ is the corresponding mass fraction. Considering that only the percentages of sand (S), loam (L) and clay (C) were available and that the factor $\log _{10}\left(\sqrt{ } d_{i} d_{i-1}\right)$ is -3.5 for $\mathrm{C}$, 2.0 for $\mathrm{L}$ and -0.5 for $\mathrm{S}$, the following simplified formula is used (Borselli, 2006): $D_{g}=0.01$ (-3.5C -2.0L -0.5S).

\section{Slope and length factors}

The slope $(S)$ and length $(L)$ factors represent the topographic constraints and estimate the effects of slope angle and slope length on the sheet and rill erosion. To capture the effect of flow convergence, the $L S$ factor is computed with the upslope contributing area per unit lenght (Desmet and Govers, 1996; Mitasova et al., 1996; 1998) by using the equation of Mitasova et al. (1996):

$$
l S=(m+1) \cdot\left[\frac{A}{a_{0}}\right]^{m} \cdot\left[\sin \left(\frac{b}{b_{0}}\right)\right]^{n}
$$

where

$A$ is the upslope contributing area;

$b$ is the slope angle,

$a_{0}$ and $b_{0}$ are the length $(22.1 \mathrm{~m})$ and slope (0.09) standard RUSLE values;

$m$ and $n$ are parameters related to the prevailing type of flow and soil condition.

Using the hydrological extension of ArcGIS release 9.1, the $L S$ factor is estimated from a digital elevation model (DEM) of Sele River basin with a grid size of $20 \mathrm{~m}$. This spatial resolution minimizes the effect of grid size on the soil loss value assessment (Lee and Lee, 2006; Rojas et al., 2008).

To this aim, four main steps were followed to define the upslope contributing area: i) the depressionless DEM was assessed by filling the sinks recognized in the DEM (Hutchinson, 1989); ii) the depressionless DEM was used to determine the flow direction; iii) the flow direction was used to determine the flow accumulation; iv) a threshold value of 125 cells, based on the comparison of flow accumulation and stream network at scale 1:5.000 (Regione Campania, 1998), was applied to the flow accumulation grid to identify the area where runoff is active. The slope angle was calculated in degree by using the slope algorithm of ESRI-Spatial Analyst. The parameter $\mathrm{m}$, according to Wischmeier and Smith (1978), was defined by using a grid with variable exponent of $0.2,0.3,0.4$ and 0.5 for slope gradient $<1.1$, to 3.3 , to 4.5 and $>5 \%$, respectively. The parameter $\mathrm{n}$ was defined as 1.3 (Moore et al., 1993).

\section{Vegetation cover and land management factors}

The $\mathrm{C}$-factor value describes the effect of vegetation cover on rillinterrill erosion. Based on the Corine Land Use map of Campania on a 1:50.000 scale (SESIRCA, 2004), 27 land use classes were attributed by a specific C factor (Zanchi and Giordani, 1995; Angeli, 2004; Bakker et al., 2008; Märker et al., 2008). To urban areas and other land uses where soil is not present (i.e. bare rocks, water courses) we assigned a $\mathrm{C}$ factor value of 0 for a $a$ priori assumption (Bakker et al., 2008). To coniferous, mixed and broad-leaved forest we assigned slightly higher values (from 0.001 to 0.003 ), since in the study area the broad leaved forest are mainly represented by chestnut trees that are deciduous and therefore reduce winter protection of soil in comparison with coniferous (Angeli, 2004). Pastures was assimilated to alfalfa stand (0.02), while natural grassland was assimilated to unmanaged grassland (0.05). Moors and heathland and Sclerophyllous vegetation were

Table 1. Montly and yearly $C$ factor values.

\begin{tabular}{|c|c|c|c|c|c|c|c|c|c|c|c|c|c|c|}
\hline & \multirow[b]{2}{*}{ Rm } & \multicolumn{13}{|c|}{ C factor values for the different land uses from literature } \\
\hline & & 0.001 & 0.002 & 0.003 & 0.02 & 0.04 & 0.05 & 0.20 & 0.25 & 0.29 & 0.30 & 0.36 & 0.45 & 1.00 \\
\hline Dec & 0.08 & 0.001 & 0.003 & 0.004 & 0.03 & 0.05 & 0.06 & 0.26 & 0.32 & 0.38 & 0.39 & 0.47 & 0.58 & 1.30 \\
\hline Jan & 0.05 & 0.001 & 0.002 & 0.002 & 0.02 & 0.03 & 0.04 & 0.16 & 0.20 & 0.24 & 0.25 & 0.29 & 0.37 & 0.82 \\
\hline Feb & 0.05 & 0.001 & 0.001 & 0.002 & 0.01 & 0.03 & 0.04 & 0.15 & 0.19 & 0.22 & 0.22 & 0.27 & 0.34 & 0.75 \\
\hline Mar & 0.07 & 0.001 & 0.001 & 0.002 & 0.01 & 0.03 & 0.03 & 0.13 & 0.16 & 0.19 & 0.20 & 0.24 & 0.30 & 0.66 \\
\hline Apr & 0.04 & 0.000 & 0.000 & 0.001 & 0.00 & 0.01 & 0.01 & 0.04 & 0.05 & 0.05 & 0.05 & 0.07 & 0.08 & 0.18 \\
\hline May & 0.05 & 0.000 & 0.000 & 0.000 & 0.00 & 0.01 & 0.01 & 0.03 & 0.04 & 0.04 & 0.04 & 0.05 & 0.06 & 0.14 \\
\hline Jun & 0.04 & 0.000 & 0.000 & 0.001 & 0.00 & 0.01 & 0.01 & 0.04 & 0.04 & 0.05 & 0.05 & 0.06 & 0.08 & 0.18 \\
\hline Jul & 0.05 & 0.000 & 0.001 & 0.001 & 0.01 & 0.01 & 0.02 & 0.07 & 0.09 & 0.10 & 0.11 & 0.13 & 0.16 & 0.36 \\
\hline Aug & 0.09 & 0.001 & 0.002 & 0.003 & 0.02 & 0.04 & 0.05 & 0.19 & 0.23 & 0.27 & 0.28 & 0.34 & 0.42 & 0.93 \\
\hline Sep & 0.16 & 0.003 & 0.007 & 0.010 & 0.07 & 0.14 & 0.17 & 0.69 & 0.86 & 1.00 & 1.04 & 1.24 & 1.55 & 3.45 \\
\hline Oct & 0.17 & 0.003 & 0.006 & 0.009 & 0.06 & 0.12 & 0.16 & 0.62 & 0.78 & 0.90 & 0.93 & 1.12 & 1.40 & 3.10 \\
\hline \multirow[t]{3}{*}{ Nov } & 0.15 & 0.003 & 0.005 & 0.008 & 0.05 & 0.10 & 0.13 & 0.51 & 0.64 & 0.75 & 0.77 & 0.93 & 1.16 & 2.57 \\
\hline & & & & \multicolumn{11}{|c|}{ Adjusted C factor values for the different land uses } \\
\hline & & 0.001 & 0.002 & 0.004 & 0.02 & 0.05 & 0.06 & 0.24 & 0.30 & 0.35 & 0.36 & 0.43 & 0.54 & 1.20 \\
\hline
\end{tabular}


assimilated to shrublands, but because of missing data for distinguish dense from sparse shrubs, we used their $\mathrm{C}$ factor average value (0.05).

Complex cultivation patterns and Agro-forestry areas were assimilated to arable dense tree cover, while annual crops associated with permanent crops were assimilated to arable medium tree cover ( 0.20 and 0.25 respectively). For fruit trees and berry plantations, olive groves and vineyards, the $\mathrm{C}$ factor values $0.30,0.30$ and 0.45 , respectively were used (Angeli, 2004; Märker et al., 2008), since they were adopted in Tuscany Region that has similar conditions to southern Italy.

Considering that in SRB arable land is a mixture (both in space and in time) of different crops, in some cases also both irrigated and not irrigated, a long-term average value was used ( 0.30 from Bakker et al., 2008). Land mainly occupied by agriculture, with significant areas of natural vegetation was assimilated to arable sparse tree cover ( 0.30$)$, while it was assigned a higher value ( 0.36 from Angeli, $2004)$ to the sparsely vegetated areas. For beaches, dunes and sands we assigned the max value (1.00) of fallow (Bakker et al., 2008), because these lands are not protected by vegetation. $\mathrm{C}$ factor values were corrected considering the state of the canopy cover during the year (Table 1), by multiplying the $\mathrm{C}$ factors reported in Table 2 per the monthly rainfall erosivity index $(\mathrm{Rm}=$ ratio between monthly erosiv-

Table 2. C factor values of the different Corine land covers.

\begin{tabular}{|c|c|c|c|}
\hline CLC code & Land use & Value & Source \\
\hline 111 & Continuous urban fabric & 0 & Märker et al., 2008 \\
\hline 112 & Discontinuous urban fabric & 0 & Märker et al., 2008 \\
\hline 121 & Industrial or commercial units & 0 & Märker et al., 2008 \\
\hline \multirow[t]{2}{*}{122} & Road and rail networks and & & \\
\hline & associated land & 0 & Bakker et al., 2008 \\
\hline 141 & Green areas inside urban fabric & 0 & Bakker et al., 2008 \\
\hline 332 & Bare rocks & 0 & Bakker et al., 2008 \\
\hline 511 & Water courses & 0 & Märker et al., 2008 \\
\hline 312 & Coniferous forest & 0.001 & Angeli, 2004 \\
\hline 313 & Mixed forest & 0.002 & Angeli, 2004 \\
\hline 311 & Broad-leaved forest & 0.003 & Angeli, 2004 \\
\hline 231 & Pastures & 0.020 & Bakker et al., 2008 \\
\hline 324 & Transitional woodland shrub & 0.040 & Märker et al., 2008 \\
\hline 321 & Natural grassland & 0.050 & Bakker et al., 2008 \\
\hline 322 & Moors and heathland & 0.050 & Bakker et al., 2008 \\
\hline 323 & Sclerophyllous vegetation & 0.050 & Bakker et al., 2008 \\
\hline 242 & Complex cultivation patterns & 0.200 & Bakker et al., 2008 \\
\hline 244 & Agro-forestry areas & 0.200 & Bakker et al., 2008 \\
\hline \multirow[t]{2}{*}{241} & Annual crops associated with & & \\
\hline & permanent crops & 0.250 & Bakker et al., 2008 \\
\hline 222 & Fruit trees and berry plantations & 0.300 & Angeli, 2004 \\
\hline 223 & Olive groves & 0.300 & Märker et al., 2008 \\
\hline 211 & Non-irrigated arable land & 0.300 & Bakker et al., 2008 \\
\hline 212 & Irrigated arable land & 0.300 & Bakker et al., 2008 \\
\hline 243 & $\begin{array}{l}\text { Agriculture land, with significant } \\
\text { areas of nat. vegetation }\end{array}$ & 0.300 & Bakker et al., 2008 \\
\hline 333 & Sparsely vegetated areas & 0.360 & Angeli, 2004 \\
\hline 221 & Vineyards & 0.450 & Märker et al., 2008 \\
\hline 131 & Mineral extraction sites & 1.000 & Bakker et al., 2008 \\
\hline 331 & Beaches, dunes, sands & 1.000 & Bakker et al., 2008 \\
\hline
\end{tabular}

$\mathrm{CLC}$, Corine land covers; $\mathrm{C}$, cover and management factor; $\mathrm{C}$, cover and management factor. ity and yearly $\mathrm{R}$ ). The average of the new monthly $\mathrm{C}$ factors allowed the computation of the yearly $\mathrm{C}$ factors corrected on the basis of the annual distribution of ground cover and rainfall erosivity (Morgan, 1995). Since the vegetation cover protects the soil from raindrop impacts, a high value of the adjusted $\mathrm{C}$ factor indicates low ground cover during heavy rain periods (Vezina et al., 2006). Spatial and temporal variability of the erosion control practice factor $(\mathrm{P})$ were not considered in this study, due to insufficient data about changes in management through time.

\section{Soil loss tolerance}

A tolerable soil loss is the max annual amount of soil that can be removed before the long term natural soil productivity will be adversely affected. The impact of erosion on a given soil type, and hence the tolerance level, depends on the type and depth of soil. In this way, the tolerance level (T) for most soils in SRB reaches values of $10-15 \mathrm{Mg}$ $\mathrm{ha}^{-1} \mathrm{y}^{-1}$ for soil depth higher than $100 \mathrm{~cm}$ (Schertz, 1983). For economic reasons, soil loss in optimal farm management is often considered higher than the soil loss tolerance: soil loss tolerance for economic planning (TEP) $=2 \mathrm{~T}$ (Shi et al., 2004).
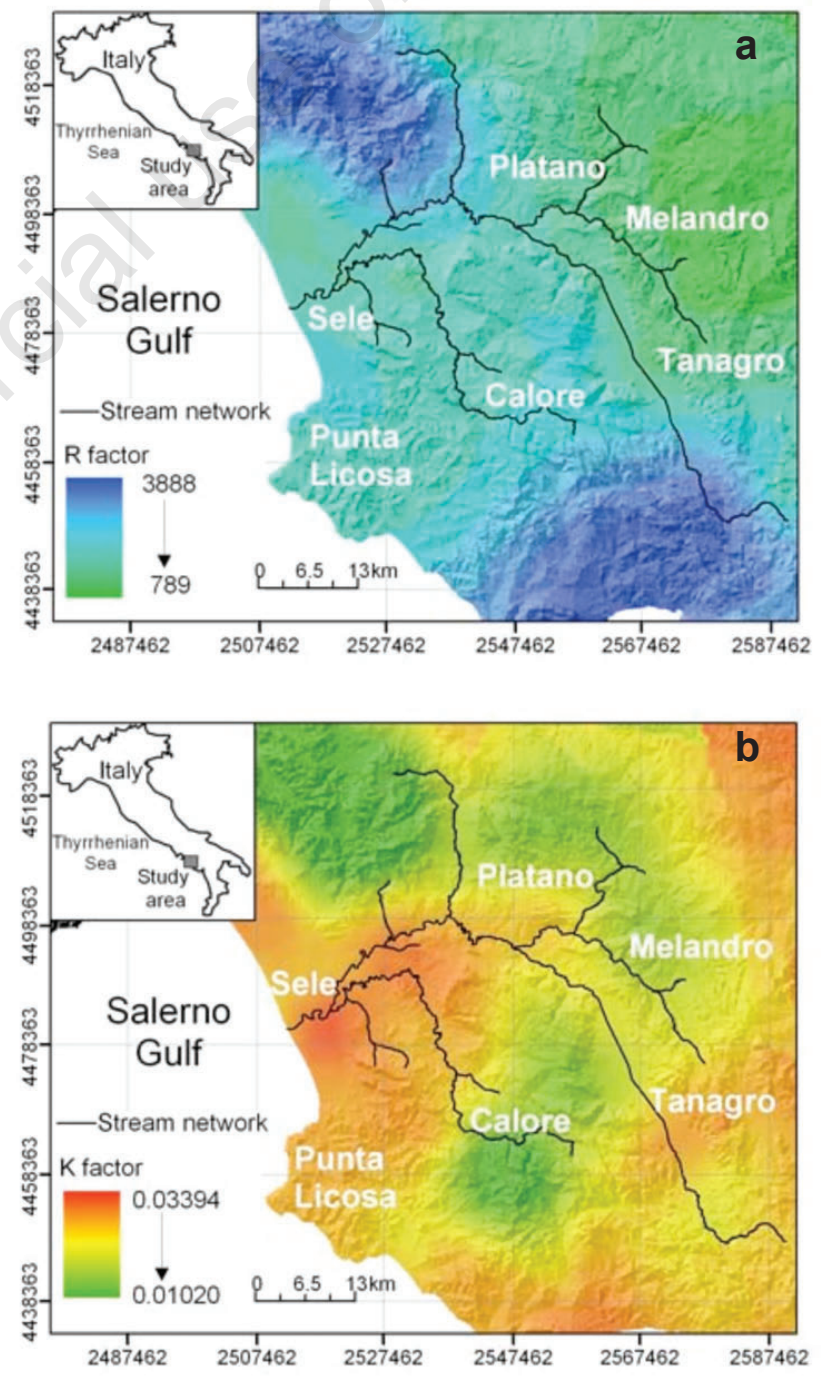

Figure 2. a) Long-term average rain erosivity; b), soil erodibility map, from: Diodato and Fagnano, 2010; Diodato et al., 2010, respectively. 


\section{Results and Discussion}

\section{Spatial pattern of erosivity and soil erodibility}

Rainfall erosivity (R) over SRB ranges from 600 to $4000 \mathrm{MJ}$ mm (ha $\mathrm{h} \mathrm{yr})^{-1}$, with mean and standard deviation of $2000 \pm 883 \mathrm{MJ} \mathrm{mm}$ (ha $\mathrm{h}$ $\mathrm{yr}^{-1}$. Figure $2 \mathrm{a}$ shows the kriging map of annual long-term R-factor with a $0.5 \mathrm{~km}$ grid resolution (Diodato and Fagnano, 2010), indicating that the annual rainfall erosivity has a moderate spatial variability in SRB. The soil erodibility map (Figure 2b) was derived from a new approach used for improving the spatial variability estimates reported in Diodato et al. (2010). Soil erodibility increases from the mountainous areas, where Mesozoic carbonates largely crop out (Platano, Melandro and Calore sub-basins), to the Sele alluvial plain, where erodibility values are very high [ $>0,03 \mathrm{Mg} h\left(\mathrm{MJ} \mathrm{mm}^{-1}\right]$.

\section{Slope-lenght and crop grid maps}

The highest $L S$ factor values in the SRB characterize the zones with
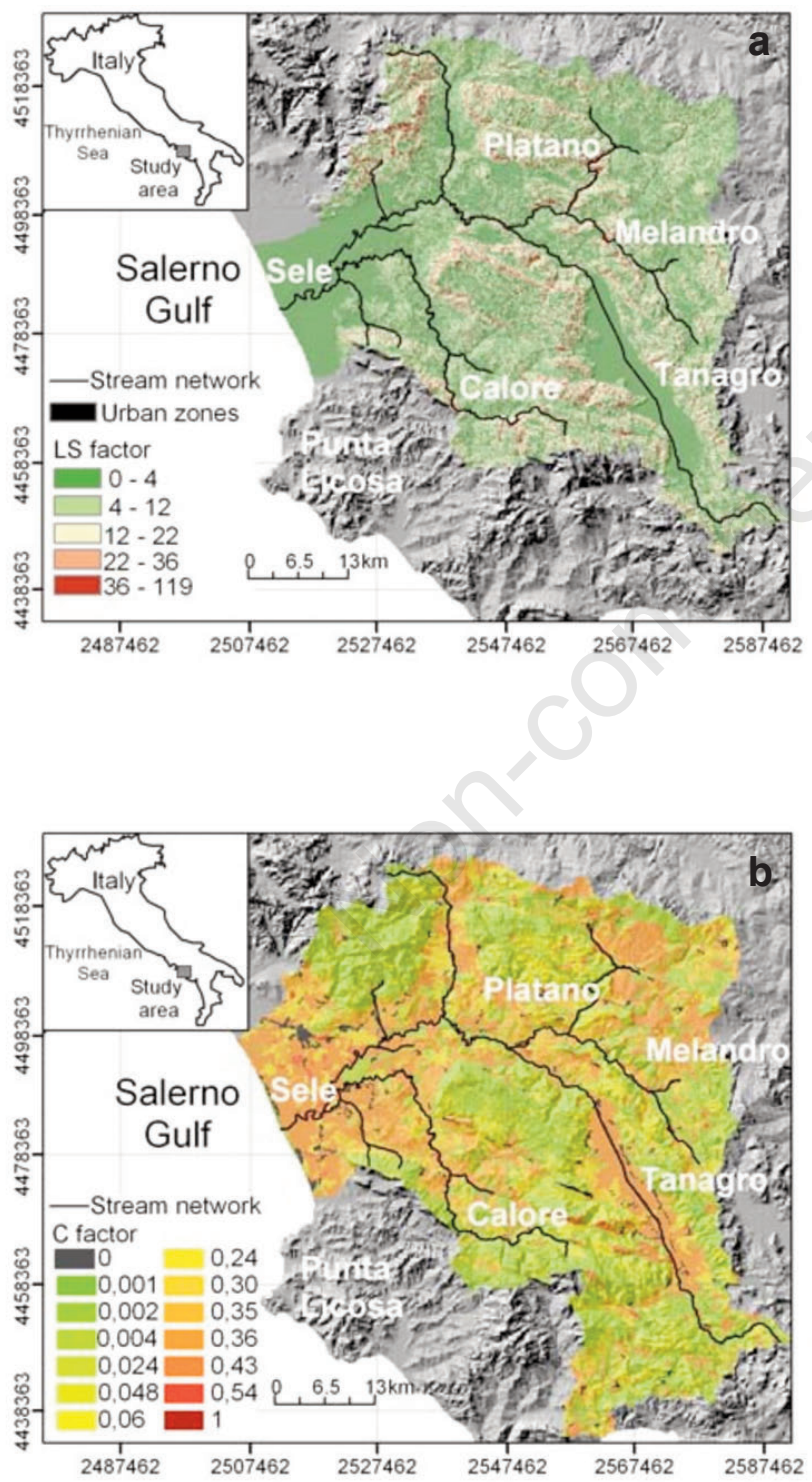

Figure 3. a) Map of Slope-and-Length (R)USLE factors; b) vegetation cover map. steeper and longer slopes (Figure 3a). By applying the $\mathrm{C}$ factor according to the different land uses of the study area (Table 2), also the landcover map was drawn (Figure $3 \mathrm{~b}$ ).

From this map, it is clear that the vegetation covers with the lowest protection of soil are the arable lands and the olive groves and vineyard, mainly concentrated in the plains and in the hilly areas.

\section{Mapping and classifying sediment source areas}

Although the $\mathrm{C}$ factor-map in Figure $3 \mathrm{~b}$ shows the the highest part of $\mathrm{SRB}$ is covered by vegetation with low $\mathrm{C}$ values (forest $\sim 50 \%$ ), in Figure 4a it can be seen that SRB is a region where soil erosion by water is an actual problem. In this map, the amount of the soil losses per year from each grid-cell is calculated on the basis of the rainstorm events averaged upon a long-term annual period. Their values range from 0 to $1000 \mathrm{Mg} \mathrm{ha}^{-1} \mathrm{y}^{-1}$ with mean rates of soil losses of $53 \pm 43$ (SD) $\mathrm{Mg} \mathrm{ha}^{-1} \mathrm{y}^{-1}$. Using the soil delivery ratio (SDR), as defined in Diodato et al., (2009), about the $80 \%$ of the eroded soils were trapped in the depressions and valleys during the transport process via drainage network. This is in agreement with simulation results of WEPP model of
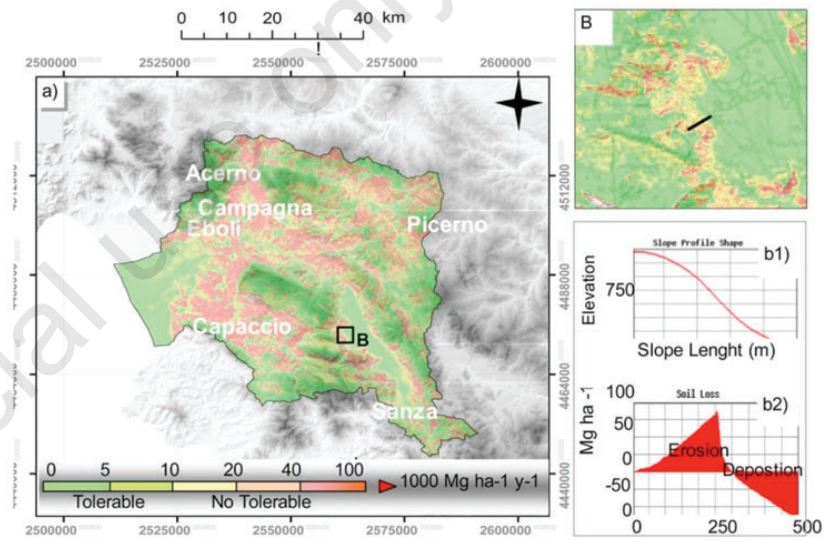

Figure 4. a) Long-term average of soil loss rate map RUSLE -based across Sele River Basin; b1) typical hill slope profile extrapolated from location $\mathrm{B}$, as indicates on the zoomed map with inclined black line, and corresponding soil mobilized along the profile (b2), as arranged from prototype version of the WEPP model web-interface of the National Soil Erosion Research Laboratory-USA (http://topsoil.nserl.purdue.edu/nserlweb/ weppmain/).

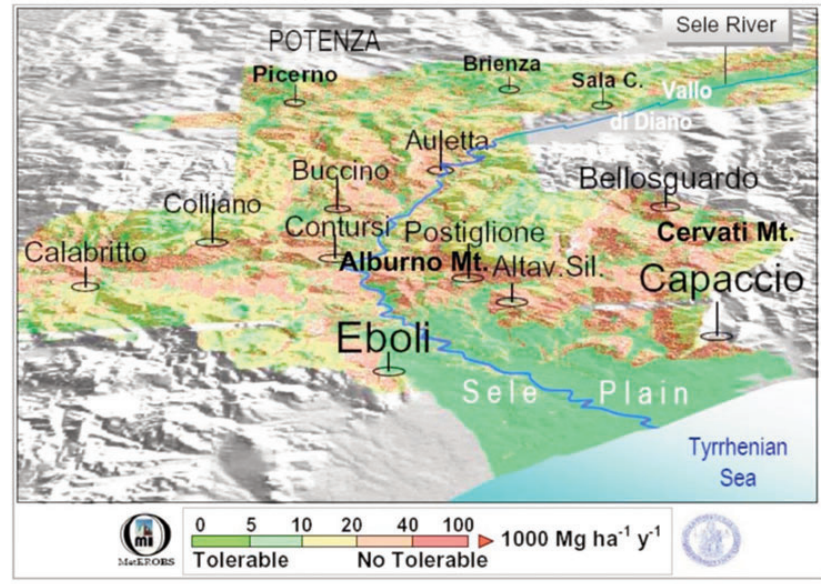

Figure 5. Perspective view of Sele river landscape from outlet towards Tyrrhenian Sea overlaid with a soil erosion classification, produced with the support of 3D-Scene's software ESRI. 
the National Soil Erosion Research Laboratory (USA) realized in the Diano Valley, (http://topsoil.nserl.purdue.edu/nserlweb/weppmain/) along a typical hill slope profile (Figure $4 \mathrm{bl}$ ) .

The WEPP model predicted the erosional and depositional trends, along the selected profile (Figure 4b2). After the first phase of soil detachment, there was a strong increase of the erosion rate (until 90 $\mathrm{Mg} \mathrm{ha}^{-1}$ ) along the higher slopes (33\%). Afterwards, at about $300 \mathrm{~m}$ along slope-length, the material eroded upstream is settled down, and only a small part of it was conveyed in the main hydrographic network.

In order to depict a best visualization of areas characterized by critical erosion rates, a classification with a tolerable-and-no tolerable soil loss is linked to the legend of Figure 4a. The tolerance threshold for economic planning TEP $=20 \mathrm{Mg} \mathrm{ha}^{-1} \mathrm{y}^{-1}$, for soil depth $>100 \mathrm{~cm}$ is considered. In this way, $32 \%$ of the basin was subjected to no-tolerable soil losses, and about $7 \%$ was affected by catastrophic erosion (e.g., rates $>80 \mathrm{Mg} \mathrm{ha}^{-1} \mathrm{y}^{-1}$ ). The remaining $68 \%$ of the basin was protected by important erosive processes, however, about $9 \%$ of its territory still remains vulnerable because of the low soil profile depth, local shallow hilly-lands, lower weathering rates and eventual salinitasion that can exacerbate soil degradation.

\section{Geovisualization of erosion processes}

The foothills and the greatest part and hilly areas are affected by erosion rates exceeding the tolerable threshold of soil loss. Furthermore, comparing topography and land-cover (Figure 3a,b) with soil loss of Figure 5 , it is evident that soil erosion rates exceed the acceptable thresholds on a wide range of landforms throughout the basin with medium-low slopes and medium-high $\mathrm{C}$ and $\mathrm{K}$ values. This is more easily perceptible from the perspective view of Figure 5, where the red areas Cilento siliciclastic hills located between the carbonate ridges of Mt. Alburno and Mt. Cervati, made of marls, sandstone, clay and conglomerate, to the clay and other terrigenous rocks of the upper Sele Valley as well as to the Pliocene-Pleistocene clastic successions of the Auletta basin (Gioia and Schiattarella, 2010). Wide areas of the Vallo di Diano basin and Sele plain, are classified with negligible soil loss (green areas) because of the very low slope. Increases of soil erosion, but still below TEP, typify the low-mountain areas, with estimated rates around $10 \mathrm{Mg} \mathrm{ha}^{-1} \mathrm{y}^{-1}$. The results show that $30 \%$, is subjected to uncontrolled erosion, while in about $10 \%$ of area, the erosion could be controlled with appropriate soil management practices.

These results are derived from a soil erosion map based on long-term average erosivity pattern. However, geomorphological processes can be dominated by few severe and stochastically rainstorms, that are not represented by RUSLE model. It is interesting to note that, although runoff, and the consequent sediment transport, experienced a common decrease over recent decades, extreme rainfalls and erosivity are growing in an erratic way, leading to a greater and chaotic mobilization of soil across the Sele basin, as reported by Diodato et al. (2009). This evidently creates not only socio-economical costs but hazardous environmental impacts because of repeated dispersion in rivers of chemical nutrient, previously lost with the soil erosion.

\section{Modelling assumption and validation}

As mentioned above, the spatial variability of rainfall erosivity (Diodato and Fagnano 2010) and soil erodibility (Diodato et al., 2010) are the major sources of uncertainty in RUSLE-GIS approach. Also the accuracy of DEM can affect up-slope contributing area and slope that are used to calculate $L S$ factor. Mitasova et al. (1996) model the propagation of uncertainty in the prediction of I by interpolating a DEM to finer spatial resolution, suggested that a DEM at a spatial resolution coarser than $20 \mathrm{~m}$ is insufficient to calculate the up-slope contributing areas. Gertner et al. (2002) supported this assertion. Conversely, Awa et al. (1987) studied the effects of three spatial resolutions $(0.25,1$ and
4 ha) on the prediction of the RUSLE using three non-parametric tests and did not find statistically significant differences in the predicted sediment loading due to cell size. Molnár and Julien (1998) instead showed that, although large grid sizes tend to underestimate soil losses in RUSLE model, a correction factor must be included only when DEM-grid sizes exceeds $100 \times 100 \mathrm{~m}$. Rojas et al. (2008), found that at grid sizes coarser than $150 \mathrm{~m}$, the sediment source areas became less appropriately depicted by RUSLE and that therefore the best results to simulate soil erosion can be obtained at grid sizes smaller than $150 \mathrm{~m}$. Therefore a cell resolution of $20 \mathrm{~m}$ adopted in this work could be considered appropriate for the geomorphological feature of the SRB.

The RUSLE model validation was not possible, because direct measurements of soil erosion were not available in the SRB. However, the estimates here calculated ( $53 \mathrm{Mg} \mathrm{ha}^{-1} \mathrm{y}^{-1}$ ), are within the $95^{\text {th }}$ confidence interval of $53-93 \mathrm{Mg} \mathrm{ha}^{-1}$ per year, found in the same basin by previous simulations made with the CliFEM-approach calibrated on a close basin (Diodato et al., 2009).

\section{Conclusions}

By integrating geographic information system and the revised universal soil loss equation, the soil erosion map of Sele River basin was drawn. The spatial and geostatistical analysis, available in GIS framework, allowed a spatial assessment of the erosion hazard over the study area.

The results suggest that soil erosion rates exceeding tolerable thresholds affect about 50\% of SRB area involving different types of soils and land uses, that mainly correspond to the hilly areas located between the carbonate mountains bounding the study area.

In these areas, showing high-very high soil erosion hazard, a strategic program for a more detailed erosion mapping is necessary to define in advance the impacts of land use change. This could allow the identification of the agricultural management practices more suitable for soil protection in the different cropping systems, such as perennial cover crops in fruit trees, olive groves and vineyard or conservative agronomic techniques (i.e. sod-seeding, minimum tillage) in arable lands.

\section{References}

Amato V., Avagliano G., Cinque A., Cipriani M., Di Paola G., Pontrandolfo A., Rosskopf M.C., Santoriello A., 2009. Geomorphology and geoarchaeology of the Paestum area: modification of the physical environment in historical times. Méditerranée 112:129-135.

Angeli L., 2004. Valutazione del rischio erosione applicazioni del modello RUSLE. Centro Ricerche Erosione Suolo, Report 2004, 21 pp. (Last access: Sept. 23, 2009). Available from: http://www.lammacres.rete.toscana.it/rapporti/2004/2.pdf

Awa T.W., Byler R.K., Shanholtz V.O., Mostaghimi S., Dillalsa T.A., 1987. DEM resolution effects on prediction of the Universal Soil Loss Equation (USLE). Am. Soc. Agric. Engin. 30:87-108.

Bakker M.M., Govers G., Van Doorn A., Quetier F., Chouvardas D., Rounsevell M., 2008. The response of soil erosion and sediment export to land-use change in four areas of Europe: the importance of landscape pattern. Geomorphology 98:213-226.

Barra D., Calderoni G., Cinque A., De Vita P., Rosskopf M.C., Russo Ermolli E., 1998. New data on the evolution of the Sele River coastal plain (Southern Italy) during the Holocene. Il Quaternario 11:287299.

Barra D., Calderoni G., Cipriani M., De La Geniere J., Fiorillo L., Greco 
G., Mariotti Lippi M., Mori Secci M., Pescatore T., Russo B., Senatore M.R., Tocco Sciarelli G., Thorez J., 1999. Depositional history and palaeogeographic reconstruction of Sele coastal plain during Magna Grecia settlement of Hera Argiva (Southern Italy). Geologica Romana 35:151-166.

Bartole R., Savelli C., Tramontana M., Wezel F., 1984. Structural and sedimentary features in the Tyrrhenian margin of Campania, Southern Italy. Mar. Geol. 55:163-180.

Bintliff J., 2002. Time, process and catastrophism in the study of Mediterranean alluvial history: a review. In: P. Rowley-Conwy (ed.) Ancient Ecodisasters. Routledge, London, UK, pp 417-435.

Blaschke P.M., Trustrum N.A., Hicks D.L., 2000. Impacts of mass movement erosion on land productivity: a review. Progr. Phys. Geog. 24:21-52.

Boardman J., 1993. The sensitivity of downland arable land to erosion by water. In: Thomas, D.S.G. and Allison, R.J. (eds), John Wiley \& Sons, 211-228.

Borselli L., 2006. Valutazione dell'erodibilità del suolo in applicazioni a scala di bacino. In: E.A.C. Costantini (ed.) Landscape Sensitivity, Metodi di valutazione dei suoli e delle terre. Cantagalli Ed., Siena, Italy, pp 922.

Brancaccio L., Cinque A., Belluomini G., Branca M., Delitala L., 1986. Isoleucine epimerization dating and tectonic significance of upper Pleistocene sea level features of the Sele Plain (Southern Italy). Z. Geomorphol. Supp. 62:159-166.

Brancaccio L., Cinque A., Russo F, Santangelo N., Allegri L., Alessio M., Improta S., Belluomini G., Branca M., Delitala L., 1988. Nuovi dati cronologici sui depositi marini della piana del Sele e della costa settentrionale del Cilento (Campania). Atti $74^{\circ}$ Congresso Società Geologica Italiana, Sorrento, Italy, pp 55-62.

Burrough P.A., 2001. GIS and geostatistics: essential partners for spatial analysis. Environ. Ecol. Stat. 8:361-377.

Camarasa Belmonte A., Segura Beltrán F., 2001. Flood events in Mediterranean ephemeral stream (ramblas) in Valencia region, Spain. Catena 45:229-249.

Cinque A., Guida M., Russo F., Santangelo N., 1988. Dati cronologici e stratigrafici su alcuni depositi continentali della Piana del Sele (Campania): i "Conglomerati di Eboli". Geogr. Fis. Dinam. Quat 11:39-44.

Desmet P. J. J., Govers G., 1996. Comparison of routing algorithms for digital elevation models and their implications for predicting ephemeral gullies. Int. J. Geogr. Inform. Syst. 10:311-331.

Diodato N., 2004. Estimate RUSLE's rainfall factor in the part of Italy with a Mediterranean rainfall regime. Hydrol. Earth Syst. Sc. 8:103107.

Diodato N., 2005a. Geostatistical uncertainty modelling for the environmental hazard assessment during single erosive rainstorm events. Environ. Monit. Assess. 105:25-42.

Diodato N., 2005b. The influence of topographic co-variables on the spatial variability of precipitation over little regions of complex terrain. Int. J. Climatol. 25:351-363.

Diodato N., Alberico I., Fagnano M., 2009. CliFEM - Climate Forcing and Erosion Modelling at Long-Term Sele River Research Basin (Southern Italy). Nat. Hazard Earth Sys. 9:1693-1702.

Diodato N., Ceccarelli M., 2004. Multivariate Indicator Kriging approach using a GIS to classify Soil Degradation for Mediterranean agricultural lands. Ecol. Indic. 4:177-187.

Diodato N., Fagnano M., 2010. A simple geospatial model climate-based for designing erosive rainfall pattern. Chapter 17 in: A.E. Nemr (ed.) Environmental Pollution and its relation to Climate Change. Nova Science Publ., New York, NY, USA.

Diodato N., Fagnano M., Alberico I., Chirico G.B., 2010. Mapping soil erodibility from composed data set in Sele River Basin, Italy. Nat. Hazards DOI 10.1007/s11069-010-9679-2.
Gertner G., Wang G., Fang S., Anderson A.B., 2002. Effect and uncertainty of digital elevation model spatial resolutions on predicting the topographical factor for soil loss estimation. J. Soil Water Conserv. 57:164-174.

Gioia D., Schiattarella M., 2010. An alternative method of azimuthal data analysis to improve the study of relationships between tectonics and drainage networks: examples from southern Italy. Z. Geomorphol. 54:225-241.

Gobin A., Govers G., Jones R., Kirkby M., Kosmas C., 2003. Assessment and reporting on soil erosion. Technical Report 94, Anna Rita Gentile (Project Mng.) European Environment Agency, 101 pp.

Hutchinson M.F., 1989. A new procedure for gridding elevation and stream line data with automatic removal of spurious pits. J. Hydrol. 106:211-232.

Ippolito F., Ortolani F., Russo M., 1973. Struttura marginale tirrenica dell'Appennino Campano: reinterpretazione di dati di antiche ricerche di idrocarburi. Mem. Soc. Geol. It. 12:227-250.

Johnston K., Ver Hoef J.M., Krivoruchko K., Lucas N., 2001. Using ArcGis Geostatistical Analyst. ESRI Ed., Redlands, CA, USA.

Kosmas C., Danalatos N., Cammeraat L.H., Chabart M., Diamanopoulos J., Farand R., Gutierrez L., Jacob A., Marques H., MartinezFernandez J., Mizara A., Moustakas N., Nicolau J.M., Oliveros C., Pinna G., Puddu R., Puigdefabregas J., Roxo M., Simao A., Stamou G., Tomasi N., Usai D., Vacca A., 1997. The effect of land use on runoff and soil erosion rates under Mediterranean conditions. Catena 29:45-59.

Le Bissonnais Y., Montier C., Jamagne M., Daroussin J., King D., 2002. Mapping erosion risk for cultivated soil in France. Catena 46:207220.

Lee G.S., Lee K.H., 2006. Scaling effect for estimating soil loss in the RUSLE model using remotely sensed geospatial data in Korea. Hydrol. Earth Syst. Sci. Discuss. 3:135-157.

Märker M., Angeli L., Bottai L., Costantini R., Ferrari R., Innocenti L.,, Siciliano G., 2008. Assessment of land degradation susceptibility by scenario analysis: A case study in Southern Tuscany, Italy. Geomorphology 93:120-126.

Mitasova H., Hofierka J., Zlocha M., Iverson L.R., 1996. Modeling topographic potential for erosion and deposition using GIS. Int. J. Geogr. Inf. Sci. 10:629-641.

Mitasova H., Mitas L., Brown W. M., Johnson D., 1998. Multidimesional Soil Erosion/Deposition Modeling and visualization using GIS. Final report for USA CERL. University of Illinois, Urbana, IL, USA.

Molnár D.K., Julien P.Y., 1998. Estimation of upland erosion using GIS. Comput. Geosci. 24:183-192.

Moore I.D., Turner A.K., Wilson J.P., Jenson S.K., Band L.E., 1993. GIS and land-surface-subsurface process modeling. In: M.FR. Goodchild, B.O. Parks and L-T- Steyaert (eds.) Environmental modeling with GIS. Oxford University Press, New York, NY, USA, pp 196-230.

Morgan R.P.C., 1995. Soil erosion and conservation, 2nd ed. Longman, Harlow, UK.

Panagopoulos T., Antunes M.D.C., 2008. Integrating Geostatistics and GIS for Assessment of Erosion Risk on Low Density Quercus suber Woodlands of South Portugal. Arid Land Res. Manag. 22:159-177.

Ramos M.C., Mulligan M., 2003. Impacts of climate variability and extreme events on soil hydrological processes. Geophys. Res. 5:92115.

Regione Campania, 1998. Cartografia Tecnica regionale. (Accessed: Sept. 24, 2009). Available from: http//www.sito.regione.campania.it/territorio/regionecampania.htm

Renard K.G., Foster G.R., Weesies G.A., McCool D.K., Yoder D.C., 1997. Predicting soil erosion by water: a guide to conservation planning with the revised Universal Soil Loss Equation (RUSLE). USDA, Agricultural Handbook No. 703, Government Printing Office, 
Washington, DC, USA.

Renschler C.S., Harbor J., 2002. Soil erosion assessment tools from point to regional scales-the role of geomorphologists in land management research and implementation. Geomorphology 47:189209.

Renschler C.S., Mannaerts C., Diekkruger B., 1999. Evaluating spatial and temporal variability in soil erosion risk-rainfall erosivity and soil loss ratios in Andalusia, Spain. Catena 34:209-225.

Rojas R., Velleux, M., Julien, P.Y., Johnson, B.E., 2008. Grid Scale Effects on Watershed Soil Erosion Models. J. Hydrol. Engin. 13:793-802.

Savenije H.H.G., 2009. The art of hydrology. Hydrol. Earth Syst. Sc. 13:157-161.

Schertz D.L., 1983. The basis for soil loss tolerances. J. Soil Water Conserv. 38:10-14.

SESIRCA, 2004. Settore Sperimentazione Informazione Ricerca e Consulenza in Agricoltura della Regione Campania: Carta dell'Utilizzazione Agricola dei Suoli della Campania (CUAS), Carta in scala 1/50.000. Napoli, Italy.

Shi Z.H., Cai C.F., Ding S.W., Wang T,W., Chow T.L., 2004. Soil conservation planning at the small watershed level using RUSLE with GIS: a case study in the Three Gorge Area of China. Catena 55:33-48.

Shirazi M.A., Boersma L., Hart W., 1988. A unifying analyis of soil texture: improvement of precision and extension of scale. Soil Sci. Soc. Am. J. 52:181-190.

Terranova 0., Antronico L., Coscarelli R., Iaquinta P., 2009. Soil erosion risk scenarios in the Mediterranean environment using RUSLE and GIS: An application model for Calabria (southern Italy). Geomorphology 112:228-245.

Thornes J.B., Alcantára-Ayala I., 1998. Modelling mass failure in a Mediterranean mountain environment: climatic, geological, topographical and erosional controls. Geomorphology 24:87-100.

Torri D., Poesen J., Borselli L., 1997. Predictability and uncertainty of the soil erodibility factor using a global dataset. Catena 31:1-22.

Vezina, K., Bonn, F., Pham Van, C., 2006. Agricultural land-use patterns and soil erosion vulnerability of watershed units in Vietnam's northern highlands. Landscape Ecol. 21:1311-1325.

Violante C., D’Argenio B., 2000. I travertini all'origine e nel declino dell'antica città di Poseidonia-Paestum (2500-1000 anni prima del presente). Atti del Convegno GeoBen 2000, Pubblicazione C.N.R. (GNDCI) n. 2133, Torino, Italy, pp 841-848.

Wang G., Gertner G., Singh V., Shinkareva S., Parysow P. Anderson A., 2002. Spatial and temporal prediction and uncertainty of soil loss using the revised universal soil loss equation: a case study of the rainfall-runoff erosivity R factor. Ecol. Model. 153:143-155.

Wischmeier, WH., Smith, D.D., 1978. Predicting rainfall erosion losses: a Guide to Conservation Planning. USDA, Agriculture Handbook No. 537. Government Printing Office, Washington, DC, USA.

Zanchi, C., Giordani, C., 1995. Elementi di conservazione del suolo. Pàtron Editore, Bologna, Italy.

Zuazo, V.H.D., Pleguezuelo C.R.P., 2008. Soil-erosion and runoff prevention by plant covers. A review. Agron. Sustain. Dev. 28:65-86. 